THE HERMENEUTICS OF INTERCULTURAL PASTORAL CARE:

\title{
FROM 'PSYCHE' TO 'POSITION' (HABITUS) WITHIN THE HEALING DYNAMICS OF LIFE (CURA VITAE)
}

\author{
Daniël Louw \\ Practical Theology \& Missiology \\ Stellenbosch University
}

\begin{abstract}
In a systemic approach to life care (cura vitae), position and habitus becomes more predominant as guiding constructs in theory formation for a pastoral anthropology than personality and behaviour and their relatedness to psychoanalyses. It is argued that habitus is directly connected to the Biblical principle of wisdom (sapientia), as well as to the spiritual dimension of meaning. In a praxis approach habitus should play a decisive role in intercultural care. In this regard paradigms and the analyses of the appropriateness of constructs containing dominant life views and belief systems become extremely important in the making of a pastoral diagnosis. In this regard an existential approach for an intercultural pastoral hermeneutics is proposed.
\end{abstract}

Key Words: Hermeneutics for intercultural care, Praxis of God, Dimension of phronesis, Theology as habitus, Christian spiritual healing, Cura vitae: an existential approach, Intercultural pastoral care

The basic assumption of the article is that a 'substantial' understanding of 'soul' within traditional pastoral anthropology (cura animarum) should be supplemented by a relational and systemic understanding of 'soul'. Within a Christian anthropology for care and counselling a systemic understanding ${ }^{1}$ of soul in terms of the normative dimension of life is not only linked to the wisdom tradition of the torah, but also to the ubuntu principle ${ }^{2}$ within the tradition of African spirituality. Within the paradigmatic shift from the psychological understanding of the psyche in terms of a phenomenological interpretation of personhood and observed behavioural patterns of action, the article is an attempt to explore the concept of habitus in a practical theological hermeneutics for intercultural care. In the light of these theoretical assumptions, the core problem of the article is: What is meant by intercultural

\footnotetext{
In systems thinking the whole is more important than its parts; components do not function according to their 'nature', but according to their position in the network (Friedman 1985:15).

2 J Gathogo (2008:42-43) links the notion of ubuntu to hospitality and the generosity of giving freely without strings attached. It can be seen as a philosophy and way of life, i.e. "an unconditional readiness to share" (2008:42). It describes interdependence as described in the proverb that says: Gutri gigatuirie kingi, i.e. "All things are interdependent" (Gathago 2008:43). Ubuntu is basically both a philosophical and religious concept that defines the individual in terms of his or her relationship to others. It is supposed to articulate a basic respect and compassion for others. According to Gathogo (2008:44) ubuntu illustrates that Africans were not incapable of philosophising as GF Hegel maintained. Instead of Rene Descartes's cogito ergo sum (I think therefore I exist), the African asserts "I am because we are", or "I am related, therefore I am". According to Gathogo (2008:46) this parallels with the concretisation of Heidegger's Being as Being-with in his Daseinanalyses.
} 
pastoral care and what is the link with cura vitae $e^{3}$ and a pastoral anthropology based on the principle of 'phronesis'?

\section{'Psyche' as a Systemic Network of habitus: The Hermeneutical Dynamics of Encounter and the Relational Praxis of Life}

As a theological enterprise pastoral care should be viewed as the expression and representation of the sensitivity and compassion of the Scripture's understanding and portrayal of God's encounter, intervention, interaction, and involvement with our being human. The encounter between God and human beings takes place within the existential realm and context of everyday living; ${ }^{4}$ i.e. the 'praxis of life.' This encounter and intervention is called in traditional theology the covenantal encounter between God and human beings. In terms of practical theological terminology one can translate this covenantal encounter as the 'praxis of God'.

'Praxis ${ }^{5}$ is not merely 'practice'. Practice refers to the practicalities such as skill, technique (the how question). With 'praxis ${ }^{6}$ is meant: the intention of actions as related to meaning and destiny (intentionality as the why question, and for-what-purpose-question). In theological terminology, the praxis of God refers to the will of God (divine intentionality) as focused on the meaning and destiny of life. In the Old Testament this intentionality (phronesis) is expressed in wisdom thinking as represented by the torah.

D Browning (1991:9-10) refers to this dimension of phronesis in practical theology as the question regarding practical reason. ${ }^{7}$ And practical reasoning is embedded in patterns of thinking as expressions of human ideas and concepts, i.e. paradigmatic frameworks of the

3 For more information and background regarding the implication of the notion of cura vitae for pastoral care and counselling, see Louw 2008.

4 See in this regard the wisdom literature and tradition in the Old Testament, as well as the function of the torah in this regard. See also Schipani's research on the way of wisdom in pastoral counseling, 2003.

5 While praxis usually refers to the process of putting theoretical knowledge into practice, the strategic and organizational usage of the word emphasizes the need for a constant cycle of conceptualizing the meanings of what can be learned from experience in order to reframe strategic and operational models. (http://en.wikipedia.org/wiki/Praxis_(process).

6 Thus, for Aristotle, praxis is guided by a moral disposition to act truly and rightly; a concern to further human well-being and the good life. This is what the Greeks called phronesis and requires an understanding of other people... Practical wisdom (phronesis) involves moving between the particular and the general.

The mark of a prudent man [is] to be able to deliberate rightly about what is good and what is advantageous for himself; not in particular respects, e.g. what is good for health or physical strength, but what is conducive to the good life generally (Aristotle).

We can now see the full quality of praxis. It is not simply action based on reflection. It is action which embodies certain qualities. These include a commitment to human well being and the search for truth, and respect for others. It is the action of people who are free, who are able to act for themselves. Moreover, praxis is always risky. It requires that a person "makes a wise and prudent practical judgment about how to act in this situation".

We can say that word and action, action and reflection, theory and practice are all facets of the same idea. This action is not merely the doing of something, what Freire describes as activism and Aristotle as poiesis. Poiesis is about acting upon, doing to: it is about working with objects. Praxis, however, is creative: it is other-seeking and dialogic. K Smith 1999: http://www.infed.org/biblio/b-praxis.htm

7 See in this regard the argument of R Osmer (2008:163). He opts for a cross-disciplinary dialogue in a communicative model of rationality. In this model 'rationality' (in my understanding, rational categories, social and cultural constructs and paradigms as bearers of ideas for the interpretation of life events) is viewed as a special form of communication in which people offer reasons to others in support of their assertions. 
human mind, as well as processes of imagining. ${ }^{8}$ These frameworks are reasonable and rational representations of convictions and philosophies of life (meaning). ${ }^{9}$ They are shaped by cultural contexts, expressed in metaphors and portrayed by symbols.

Ed Farley in Practical Theology (1983:27) argues that theologia practica is simply the habitus viewed as to its end (from the spiritual perspective of the ultimate). "Practice meant that aspect of habitus, or wisdom, in which the divine object sets requirements of obedience and life. Both reside in the single existential habitus called theology. Theory/practice is based here on what could be called a phenomenology of theology as habitus" (1983:27).

The basic assumption in such a description of practical theology is the notion that a close relationship exists between what is meant by praxis and the concepts of wisdom and habitus. However, in the history of practical theology, and within different models, it was not always the case. Praxis in practical theology is often interpreted as ministerial models and strategies within the realm of merely human actions (practicalities).

The abovementioned emphasis on habitus within a theologia practica has indeed implications for anthropology in pastoral theology. Therefore the following question: is it possible in terms of exegesis and a Biblical hermeneutics to shift from the substantial understanding of 'soul' or 'psyche' to a more systemic and relational understanding of soul within life-terminology?

\section{Soul: from 'Imprisonment' to 'Embodiment'}

The use of the term 'soul' in Scripture refers to human wholeness and not to a different substance, as in the case of Hellenism. Plato, for example, provides us with the idea that a soul can be deprived of its body; that it does not come fully into its own until it has been separated from the body, and that it is immortal. The body is therefore merely clothing for the soul, a kind of prison from which it should escape and be liberated.

In the Bible different concepts are used to denote 'soul'.

The word for psyche (psuche) is derived from a root that means breath, or to breathe. The Hebrew word for soul, nephesh (Gen 2:7) means breath, exhalation, and the principle of life (Seidl 1999:751, Brown 1978:679-680). Nephesh denotes a principle of life that makes a body, whether human or beast, into a living being. When nephesh is translated as psyche ${ }^{10}$ it signifies that which is vital in a human being in the broader sense. In combination with heart (kardia) and mind (nous), soul in the New Testament describes the seat of life or even life itself. It represents the person in the broadest sense and indicates the quality of life experiences. Soul therefore does not refer in the first place to a different anthropological category, but to a different mode of being (Harder in Brown 1978:684).

Our interpretation of both nephesh and psyche should take account of the fact that the worldview of the Old and the New Testament functioned within totally different contexts and paradigms to ours. When we read Scripture we are bound to our own cultural context.

8 Imagining can refer to the power of improvisation. AG Reddie refers to Jesus as a jazz musician and the possibility of a jazz hermeneutics. It includes the power of improvisation. "It is the power of responding to circumstances in such a way that the 'givenness' of the context is radically re-altered and something startling and new emerges" (2008:57). Jesus's engagement is one that straddles the tension between that which exists (the tradition of Judaism) and that which is becoming (the reinterpretation of tradition).

9 Meaning-identification (Sinduiding, Sinndeutung) can then be identified as a fundamental endeavour of practical theology.

10 For the meaning of psyche and the connection with life, see Dunn 1998:76: "For both terms (psyche/nephesh and pneuma/ruach) express an original identification of 'breath' as the life 'force"'. 
It is therefore obvious that different schemata of interpretation will play a role in our findings. For our discussion it is important to mention that both nephesh and psyche in Scripture refer to life and its quality (Seidl 1999:751); (see Mt 16:25, Jn 15:13).

Our argument for soul as embodiment and as an indication of our being functions does not deny the notion of the uniqueness of the individual, nor the experience of autonomy as a unique way of being human; i.e. the experience of mine (Meininger 2001:17). Because of the Christian belief that humans are made in the image of God, our individuality implies a representation of the character of God (love/grace).

In a pastoral and theological anthropology one cannot ignore totally a 'substantial' approach. 'Substantial' here refers to authenticity and the stance of the individual before God. On the one hand, substantiality depicts a state of being and a qualitative condition as determined by grace. On the other hand, a relational approach helps one to understand authenticity within the dynamics of networking. One should therefore opt for an inclusive anthropology, which operates with both the mutuality of relationships (relatio), as well as the identity of being qualities (substantia), rather than an anthropology in which substantia predominates (see Meininger 2001:20).

Soul describes a specific stance in life, a disposition within life events. It connects with choices (ethical dimension) and reveals character (epitedeumata). It also connects with acts which express intention and motivation/driving forces (praxeis). Human soul therefore also represents an appropriate ethical stance in life and is expressed in virtues. Virtue (arête) means "the specific quality appropriate to an object or a person" (Link and Ringwald 1978:925). The fruit of the Spirit (Gal 5:22) can be viewed as a Christian equivalent of the general human virtues; virtues are "actions of God's new creation" (Link and Ringwald 1978:927).

Because of the important role of attitude ${ }^{11}$ (phronesis) in the revelation of God to human beings, a close relationship between attitude/disposition and soul is presupposed. According to Philippians 2:5, wisdom or attitude plays a decisive role within the being functions of Christians: In the light of the centrality of Philippians 2:5 and its understanding of God's intention with salvation (the 'soul' of God), phronesis seems to be a very appropriate choice. It refers both to an eschatological understanding of the quality of our being human, as well as to the existential consequences for our Christian identity.

The word for attitude (phronesis) is related to the Old Testament's understanding of wisdom (Goetzman: 1976:616). The Hebrew equivalents are hakom and bîn with their respective derivations. What is significant is the fact that phronesis is related to God's position. It denotes a creative understanding of God in which wisdom (sophia), together with the notion of Christ's incarnation, plays a fundamental role. Our position can be summarised in the following quotation:

'Soul' is not a thing, but a quality or a dimension of experiencing life and ourselves. It has to do with depth, values, relatedness, heart and personal substance (Moore 1992:5). ${ }^{12}$

11 In this regard it is useful to mention that even in the Classical outlook on our being human, the concept of sophrosyne, was used as an indication of one's self-understanding in relationship to the immortal gods who punished undue pride (hybris). "In tragedy the moral lesson was to cultivate sophrosyne, a proper balance and awareness of one's true position" (Starr $1981^{10}: 65$ ).

12 See in this regard the argument in Nauer 2005:471 for cura animarum and its connectedness to nephesh Humans don't have nephesh, they are nephesh (2005:472). We are in our totality soul, in all relations. 


\section{Integrative Spiritual Healing: The Existential Dimension of our Human Quest for Meaning in Life}

Spiritual healing does not imply that all the problems of life are solved, but rather that one understands God and relates one's God image to life in order to live the problems in an appropriate and responsible way. Spiritual healing occurs when one can relate an appropriate understanding of God to the basic issues in life. Healing ${ }^{13}$ is about the encounter between life and God, and the quality of our being functions which emanate from such an encounter, as well as an awareness of the presence of God (the coram Deo principle) that inspires and motivates faith. Inspired faith is a pneumatological event that fosters a directed courage to be and leads to inspiring and transforming actions of hope. The further argument will be that the categories of meaning, ${ }^{14}$ destiny (telos) and Intimacy/Geborgenheit ${ }^{15}$ are essential for a hermeneutical and systemic approach to integrative spiritual healing. ${ }^{16}$

\section{Spiritual Healing}

If Christian spiritual healing wishes to create an intimate space of 'geborgenheid', the following theological principles and perspectives regarding spiritual healing are relevant:

- Spiritual healing as a new state of being: healing represents the fact that "if anyone is in Christ, he/she is a new creation" (2 Cor. 5:17). This is a shift from sin into the eschatological realm of redemption and salvation;

- Spiritual healing as new state of mind: peace. Shalom describes a contentedness with God and life. "For he himself is our peace" (Eph. 2:14);

- Spiritual healing as a new attitude and way of doing and living. "Live by the Spirit $\ldots$ the fruit of the Spirit is love, joy, peace, patience, kindness, goodness, faithfulness, gentleness and self-control" (Gal. 5:16; 22-23);

- Spiritual healing as wholeness, purposefulness and direction. "For in this hope we were saved" (Rom 8:24).

One of the basic assumptions in cura vitae is that spiritual healing with its dimensions of peace (shalom), healing (habitus) and wholeness (telos, meaning) should take place within the realm of existential, life issues. Therefore the following emphasis on an existential approach.

The real and most fundamental healing of the human 'soul' occurs within the existential realities of life.

\section{Cura Vitae: an Existential Approach}

The argument for a theological understanding of Christian spiritual healing is that it should have an impact on the following existential dimensions of life. ${ }^{17}$

13 For the relationship: healing (Heilung) and salvation (Heil) see Karle 2009:548-552.

14 See Wilhelm Gräb (2006:52); Landmesser (2005:127-128).

15 Religion has to do with a fundamental experience of trust (Grundvertrauen ins Dasein), and a conception of transcendence that engenders gestures or symbolic expressions of meaning and an understanding of coherence, belonging and networking in our journey as human beings through history. See Gräb 2006:53.

16 For a discussion on the connection between spirituality, an experience of transcendence, and meaning and religion, see Drehsen et al. 2005.

17 In this regard, see the 'Map of Consciousness' by D Hawkins, 2009. 


\section{- The existential threat of anxiety}

The fear of being rejected and isolated within the dynamics of human relationships. At stake for cura vitae is the following presupposition: our basic existential need is intimacy. ${ }^{18}$

- The existential threat of guilt

Guilt and feelings of guilt from our past have the potential to destroy identity and self-esteem in the present and future orientation. Our basic existential need here is freedom and deliverance. ${ }^{19}$

- The existential threat of doubt and despair

To be exposed to meaninglessness and voidness can rob one of hope. Our basic existential need is anticipation in hope..$^{20}$

- The existential threat of helplessness and vulnerability

People often become emotionally sick because they remain helpless victims within the different networks and structures of life (cf. the HIV pandemic). Our basic existential need is for a functional and available - but also viable - support system. ${ }^{21}$

- The existential threat of disillusionment, frustration, anger and unfilled needs

Anger is an expression of frustration due to unfulfilled needs. Needs are shaped by many contextual issues such as poverty, unemployment, poor housing and living conditions, violence and crime. The extreme expression of anger is aggression and violent behaviour. Our basic existential need is the fulfilment of life expectations.

In Christian spiritual care life fulfilment is indicated by two spiritual categories: gratitude and joy. Gratitude ${ }^{22}$ refers to eucharistia, good grace. ${ }^{23}$

The following table is a schematic summary of a comprehensive and existential understanding of healing and indicates what is meant by cura vitae in spiritual healing.

18 With intimacy is meant: the need to be accepted unconditionally for who you are without the fear of rejection (the quest for human dignity and identity). Spiritual healing in this regard means to discover amazing grace: "But by the grace of God I am what I am" (1 Cor 15:10). Grace refers to the theology of unconditional love.

19 Spiritual healing in this regard means forgiveness and reconciliation. "He forgave us all our sins" (Col 2:13 14). "God ... reconciled us to himself through Christ" (2 Cor 5:18).

20 Spiritual healing in this regard means trust in the faithfulness of God "May the God of hope fill with all joy and peace as you trust in him, so that you may overflow with hope by the power of the Spirit" (Rom 15:13).

21 Spiritual healing in this regard means the discovery of koinonia or fellowship i.e. the church as the body of Christ. "If one part suffers every part suffers with it" (1 Cor 12:26).

22 "A life of faith is a life of gratitude - it means a life in which I am willing to experience my complete dependence on God and to praise and to thank him increasingly for the gifts of being. A truly eucharistic life means always saying thanks to God, always praising God, and always being more surprised by the abundance of God's goodness and love" (Nouwen 20004:3).

23 Gratitude is the awareness that one's human identity is not established on the basis of any human merit or performance. It is established and affirmed by the faithfulness of God alone. Joy refers to the fact that I am a 'charismatic person', endowed, equipped for life, as well as empowered by the Spirit of God. 


\begin{tabular}{|l|l|l|l|}
\hline $\begin{array}{l}\text { Existential issues A } \\
\text { The threat to dignity }\end{array}$ & $\begin{array}{l}\text { Compulsions B } \\
\text { Excessive human } \\
\text { quests }\end{array}$ & $\begin{array}{l}\text { Life needs C } \\
\text { Being needs: courage } \\
\text { to be }\end{array}$ & $\begin{array}{l}\text { Belief system D } \\
\text { paradigm/idea } \\
\text { construct }\end{array}$ \\
\hline $\begin{array}{l}\text { Anxiety: experience } \\
\text { of loss/ rejection }\end{array}$ & $\begin{array}{l}\text { To be acknowledged } \\
\text { \& validated }\end{array}$ & $\begin{array}{l}\text { Intimacy: } \\
\text { affirmation and self- } \\
\text { actualisation }\end{array}$ & $\begin{array}{l}\text { Grace: unconditional } \\
\text { love Role of God- } \\
\text { images }\end{array}$ \\
\hline Guilt/shame & $\begin{array}{l}\text { To be perfect } \\
\text { Success }\end{array}$ & Freedom/deliverance & $\begin{array}{l}\text { Forgiveness } \\
\text { Reconciliation }\end{array}$ \\
\hline Despair/doubt & $\begin{array}{l}\text { The quest for } \\
\text { security/safety }\end{array}$ & $\begin{array}{l}\text { Anticipation: meaning } \\
\text { \& trust }\end{array}$ & $\begin{array}{l}\text { Eschatological realm } \\
\text { of hope }\end{array}$ \\
\hline $\begin{array}{l}\text { Helplessness/ } \\
\text { vulnerability }\end{array}$ & $\begin{array}{l}\text { To be independent \& } \\
\text { in control } \\
\text { (Power: dominate) }\end{array}$ & Support system & $\begin{array}{l}\text { Fellowship } \\
\text { Koinonia/Diakonia }\end{array}$ \\
\hline $\begin{array}{l}\text { Frustration/anger } \\
\text { Disappointment and } \\
\text { frustration }\end{array}$ & $\begin{array}{l}\text { To possess \& to have } \\
\text { (Greed) }\end{array}$ & $\begin{array}{l}\text { Life } \\
\text { fulfilment/direction/ } \\
\text { transformation }\end{array}$ & $\begin{array}{l}\text { Gratitude/Joy } \\
\text { Promissio-therapy } \\
\text { Sacrificial ethics }\end{array}$ \\
\hline
\end{tabular}

The implication of an existential approach to integrative spiritual healing is that the unconditional love of God provides the healing dimension and therapy of intimacy. When rejection and isolation are addressed through unconditional love and grace, change within the essence of our very being and human identity occurs. Healing on an existential is about the way in which the existential issues (A) and their connectedness to compulsions $\mathrm{B}$, is interpreted from the perspective of the Christian spiritual paradigms and ideas (belief system) D, in order to address the existential life needs $\mathrm{C}$ Therapy, healing, occurs when the spiritual categories bring about a change in habitus and a new focus on life goals and meaning (noesis).

The difficult question to be addressed right now is: how such a Christian spiritual approach is linked to the notion of culture. What is the link with interculturality in a pastoral hermeneutics to care and counselling?

\section{Intercultural Pastoral Care and the Quest for Healing: towards a Socio-systemic Approach}

At the end of the twentieth century the concept of interculturality ${ }^{24}$ emerged to indicate that an intercultural paradigm could be more appropriate than the existing paradigm of inculturality. ${ }^{25}$

Inculturation $^{26}$ in pastoral care refers to the gospel being incarnated and embodied within the paradigm of a specific local culture, without losing the awareness of multicultural pluralism, i.e. the reality of different cultures (identities) within a system of

24 Villa-Vicencio (1994:120) connects interculturality to the necessity of an interreligious dialogue. With the forging of a common sense of belonging, South Africa is in need of a cultural openness, which involves a comingling of cultures, with a presumption of equal worth.

25 The difference between inculturality and interculturality is not great. The first emphasises interpenetration while the second emphasises exchange. Bellagamba (1987:99) refers to inculturation as the attempt to create a spirituality which is rooted in the basic experience of life. The theological justification for inculturation is sought in incarnational theology. "An incarnated spirituality would be a great gift to Africans" (Bellagamba 1987:104).

26 When we use the concepts of inculturation and interculturation we must guard against the tendency to use the concept of culture as exclusive in terms of race, ethnicity and gender. Hence the argument to move 'beyond multi-culturalism' in order to combat the affirmation of cultural particularism. See Villa-Vicencio 1994:115. 
dynamic interaction and inter-dialogue. ${ }^{27}$ According to Bate (1995:2410 "it (culture) is the site of the humanisation of the oikos, and thus the site where the meeting occurs between the church as the human community of faith and the world as the human community in life". ${ }^{28}$

In the $19^{\text {th }}$ century inculturalisation tended to be no more than the 'Christianisation' of the so-called heathen culture. Such an approach implied more than accommodation. It was actually an engulfing missionary mode ${ }^{29}$ with the focus on cultural assimilation (VillaVicencio 1994:116). This model projects a Christian homogenised culture that marginalises (often alienates) those cultures that are excluded from the dominant religious point of departure. $^{30}$

Culture, ${ }^{31}$ from the Latin colo, means to nurse (take care of), or to transform the earth through a plough (an instrument) in order to live. Culture therefore refers to the human achievement and endeavour which tries to 'cultivate' creation and the cosmos into a humane space for living through symbols, metaphors, language and instruments (techne). Culture is the human attempt to 're-create' creation through spiritual-religious articulation (transcendence); ethically driven actions (norms, values, taboos); aesthetic imagination (art), technical intervention (technology); dialogical verbalisation (language and speech); and social/political/juridical restructuring into a humane environment. ${ }^{32}$

Culture as a humane environment describes the human endeavour to find meaning in life. Clifford Geertz (1997:46) describes culture, as embedded in historical context, as a system of meaning, expressed in symbolic forms. These symbolic expressions describe ways and means through which people try to shape their environment into a system of meaning. Culture therefore signifies a knowledge of, and attitude towards, life.

\section{Core Issues in Interculturality: A Challenge to Pastoral Care}

Interculturality in pastoral care ${ }^{33}$ is less about the technique of counselling (counselling and communication skills) and more about the quality of the interaction and encounter (being

27 In his book Inculturation and Healing, S C Bate (1995:19) advocates a connection between inculturation and healing.

28 HR Niebuhr's work Christ and Culture (1952) on the relationship between the Christian faith and culture, has become a classic.

29 For the impact of the colonial period and the connection with the foreign missionaries, see Bujo (1992:37-49).

30 For a long time in the missionary history in Africa, African culture was viewed from a colonial Christian perspective as inferior and the most of times intrinsically wrong. DL Daneel (1991:273-274) points out that, as far as the colonisers were concerned, non-Christian religion was profoundly influenced by human sin and imperfection. "Bavinck's term possessio is apt, since the gospel cannot be arbitrarily slotted into heathen customs, but must instead take possession of and transform them" (Daneel 1991:274). Because nothing could be assimilated into the church, the buzzword was total transformation (transformation as engulfing and extinction) of indigenous culture without the possibility of any form of accommodation.

31 For the background to the concept of 'culture', see Van Binsbergen (2003:465-469). He refers to Tylor's definition: "that complex whole which includes knowledge, belief, art, morals, law, custom and any other capabilities and habits acquired by man as a member of society." In this regard, Van Binsbergen prefers the concept 'cultural orientation' rather than merely 'culture' (2003:476).

32 As DN Hopkins (2005:83) puts it: "Culture is where the sacred reveals itself. As a result, one only knows what she or he is created to be and called to do through the human created realm of culture".

33 Interculturality is in fact a creative response to the diversity, difference and pluralism which is a fact in present-day society and the post-modern culture of globalisation. According to Lartey (1997:11) it calls for the affirmation of three basic principles: contextuality (the framework of surrounding beliefs and worldviews), multiple perspectives (the listening to and dialogue within different perspectives) and authentic participation (mutual concern for the integrity of the other). 
with skills). The core question is then: How can I encounter people coming from a different cultural background ((Schneider-Harpprecht 2002:38) without the danger of prejudice and stigmatisation, as well as the threat of xenophobia?

The core issues and challenges facing intercultural care are the following:

- A paradigm switch: from the autonomy of the individual with the emphasis on the self-culture (the myth and preoccupation with individual and personal self-maintenance) to the dynamics of eco-systemic networking (shared interconnectedness). Interculturality is about systemic thinking and care ((Weiss 2002:37). ${ }^{34}$ Within the intercultural encounter, one comes across the healthy tension between the paradox of Albrecht Grözinger (in Schneider-Harpprecht 2002:46) calls difference blindness (justice to the stranger) and difference awareness (sensitivity for difference and diversity).

- The emphasis in intercultural care is less on therapeutic talking and more on therapeutic being-with (the therapeutic encounter). It is less focused on self-expansion and more on perspective building or the widening of horizons. In a hermeneutic encounter the focus horizon-expansion (Horizonerweiterung, Federschmidt 2002:10).

- The pastoral endeavour in intercultural care is less focused on psychoanalyses (introspection in terms of personal past-events) and more on the making of a sociocultural analysis. ${ }^{35}$ In this regard Draguns $\left(1989^{3}: 6\right)$ refers to the need for a careful conceptual analysis of a culture's values and practices.

- Interculturality implies more than the traditional quest for empathy in counselling. Ridley and Lingle (1998 3 :28-32) describe the need for what they call cultural empathy (interpathy) (Augsburger 1986:29), i.e. empathy based on uniqueness and differences. Cultural empathy does not depend on cultural neutrality. On the contrary, it requires an awareness of cultural values and assumptions.

- Intercultural counselling is less focused on an emotional striptease through talktherapy (me-exposure) and more aware of the need for we-understanding through storey-telling, thus the need for narrative sharing. ${ }^{36}$ Intercultural encounters flourishes on narration (Weiss 2002:17).

- The challenge in intercultural care is how to merge the traditional understanding of 'soul care' (cura animarum) with life care (cura vitae). In this regard care is more focused on doing than on merely feeling, thus the need for the emphasis on diaconic care, pastoral care as pastoral action (Weiss 2002:29). The challenge is on the building of helping relationships, i.e. faith care as life care and life care (SchneiderHarpprecht 2002:50-52). ${ }^{37}$

- The theoretical principal for intercultural care is systemic networking. ${ }^{38}$ In order to apply the principle of systemic networking, the making of a socio-cultural analysis

34 See in this regard the 'systemischen Seelsorgermodel)'. Schneider-Harpprecht 2002:47.

35 For the making of a socio-cultural analysis, see Louw 1999:277-281.

36 "Narrativität ist auch ein Grundzug menschlichen Denkens, der im Alltag bis hin zu komplexen humanwissenschaftlichen Theorienmodellen present ist”, Schneider-Harpprecht 2002:52.

37 "Hier geht es wahrlich nicht darum, die erschütterten Seelen der Menschen zu heilen, sondern Lebensbedingungen zu schaffen, mit denen sie die Erschütterungen ertragen können”, Weiss 2002:30.

38 See 'vernetzen', Schneider-Harpprecht 2002:49. 
become paramount in intercultural care. The presupposition is that culture in itself is a systemic network of meaning (C Geertz).

- In intercultural care it is necessary to acknowledge transcendence (Lartey 1997: 5-6): To recognise a transcendent dimension to life is to take people's spiritual needs into account when assessing the network of meaning. It helps intercultural care to develop a holistic understanding of human experience.

- Intercultural care implies philosophical counselling, i.e. probing into different philosophies of life. The under girding view of life as expressed in different philosophical models, should be determined (philosophical counselling), ${ }^{39}$ for example, whether one deals with a pre-modern, modern, or postmodern society. In this regard the different schemata of interpretation should be assessed (cognitive frameworks, ideas/forms and patterns of thinking), thus the importance of philosophical counselling. ${ }^{40}$

- The skills for intercultural pastoral care are the following: Interpathy, interspection and transspection.

In his book on Pastoral Counselling Across Cultures, D Augsburger (1986:29-30) refers to inter-pathetic caring, the process of 'feeling with' and 'thinking with' another. Such an attempt requires that the one enters the other's world of assumptions, beliefs, and values and temporarily take them as one's own. He is referring to M Maruyama (1986:30) who coined the concept of 'transspection'. With transspection is then meant an effort to put oneself into the head (not shoes) of another person. While empathy is a projection of feelings between two persons in epistemology, transspection "is a transepistemological process which tries to experience a foreign belief, a foreign assumption, a foreign perspective and feelings in a foreign context "(1986:30).

\section{Conclusion}

In terms of possible future discussions, one can conclude and hypothesise that intercultural care as a hermeneutical endeavour is about the concern for:

- The interpretation and understanding of language embedded in an intercultural dialogue. The understanding of metaphors and symbols describing the meaning dimension of life should be assessed in intercultural care. (The importance of methophoric and symbolic speech).

- The identification of difference and strangeness within the reality of misunderstanding and the exposure to cultural shock (Draguns $1998^{3}: 3$ ). The awareness of social distance (Draguns $19989^{3}: 5$ ) and the 'irritation of misunderstanding' (Weiss 2002:19) are necessary for the creation of an intercultural sensitivity.

- Intercultural care deals with xenophobia: the threat of the stranger due to prejudice, stigma and discrimination. Inter-culturality is always exposed to stereotyping.

"Philosophical counselling is a relatively new but rapidly growing field of philosophy" (Marinoff 1999:7)

40 In his book Plato not Prozac, (Marinoff 1999:24) refers to the relatively recent scientization of psychology and the psychological industry with the emphasis on talk therapy and the human need for dialogue. With reference to psychoanalysis in psychotherapy most of the theories are built on the notion of post hoc ergo propter hoc, it means that because one event happened before another, the earlier event caused the later one. This cause and effect approach, combined with empathetic counselling, leads to the practice of emotional probing and memory analyses. But knowing the cause of your pain does not necessarily take the pain away or comfort one. 
Stereotyping obliterates within-group differences (Draguns $1998^{3}: 16$ ) and is thereby a threat to the notion of human dignity.

- Healing in intercultural care is not so much about behavioural change, psychoanalytical exploration/insight, a psychological catharsis, confession of sins and conversion, but about change in perspectives (perspectivism) and a different stance in life (change of position and habitus). Healing implies a multi eco-systemic intervention (Schneider-Harpprecht 2002:61), a systemic integration of difference (Weiss 2002:20) into a meaningful framework, and repositioning and reframing in terms of spiritual networking. It entails the development of a multi-systemic awareness and observation (Schneider-Harpprecht 2002:56).

- Intercultural care probe for paradigmatic changes in terms of power issues as related to the abuse of power and violent behaviour.

- In intercultural care human dignity should be understood less in terms of "American imperialistic and individualistic processes of democratisation", and more in terms of meaningful and spiritual networking. In this regard the ubuntu schema of interpretation can be most helpful. ${ }^{41}$

- Intercultural care should attend to conflict management and crisis counselling due to the problem of misunderstanding, violence and the abuse of power. Important in this regard is the spiritual principle of hospitality and reconciliation.

- Intercultural care deals with ethnicity, tribalism, pigmentocracy (discrimination due to skin and colour differences), power issues, gender inequality, and religious diversity (the need for an interfaith dialogue) and social issues such as poverty.

- Intercultural care as a branch of pastoral theology should be directed by the following theological framework and principle: i.e. the principle of hospitality. ${ }^{42}$ Hospitality in theology refers to the ethos of hosting the stranger and inviting the other to become part of the 'extended family' of God. In an intercultural setting, hospitality is the practice by which the church stands or falls (Sutherland 2006:83).

\section{BIBLIOGRAPHY}

Augsburger, DW 1986. Pastoral Counseling Across Cultures. Philadelphia: Westminister.

Bate SC 1995. Inculturation and Healing. Coping-healing in South African Christianity. Pietermaritzburg: Cluster Publications.

Bellagamba, A 1987. New Attitudes towards Spirituality. In: Aylward Shorter (ed.), Towards African Christian Maturity. Kampala: St Paul, 95-109.

Brown, C 1978. Soul. In: C Brown (ed.) Dictionary of New Testament Theology. Vol III. Exeter: Paternoster Press, 686-687.

Browning, DS 1991. A Fundamental Practical Theology. Minneapolis: Fortress Press.

Bujo, B 1992. African Theology in its Social Context. Faith and Cultural Series. New York: Maryknoll.

41 "Vernetzen als Proprium der Seelsorge", Schneider-Harpprecht 2002:49.

42 See in this regard the reflection of R Vosloo (2006:47-49; 2004:69-89) on the Biblical principle of hospitality. The basis for hospitality is the conviction in Israel that the encounter between God ans his people is based on the principle of God's hospitality (2006:64). With reference to the Christian tradition of hospitality, see Pohl 1999. 
Daneel, DL 1991. Quest for Belonging. Introduction to a Study of African Independent Churches. Gweru: Mambo Press.

Draguns, JG 1989³ . Dilemmas and Choices in Cross-Cultural Counselling: the Universal versus the Culturally Distinctive. In: JB Perderson et al, Counselling Across Cultures. Honolulu: University of Hawaii Press, 3-21.

Drehsen, V et al 2005. Kompendium Religionstheorie. Göttingen: Vandenhoeck and Ruprecht.

Dunn, DG 1998. The Theology of Paul the Apostle. Grand Rapids: Eerdmans.

Federschmidt, k h. 2002. Einführung. In: K Federschmidt et al, Interkulturelle Seelsorge. Neukirchen-Vluyn: Neukirchener Verlag, 8-14.

Friedman, EH 1985. Generation to Generation. Family Process in Church and Synagogue. New York: Guilford.

Gathogo, J 2008. African philosphy as expressed in the concepts of hospitality and Ubuntu. In Journal of Theology for Southern Africa, 130, March, 39-53.

Geertz, C 1997. Dichte Beschreibung. Beiträge zum Verstehen kultureller Systeme, 5. Aufl. Frankfurt am Mein: Suhrkamp.

Goetzman, J 1976. Mind (phronēsis). In C Brown (ed.) Dictionary of New Testament Theology. Vol. II. Exeter: Paternoster Press, 616-6 E.

Gräb, W 2000. Lebensgeschichten, Lebensentwürfe, Sinndeutungen. Eine Praktische Theologie gelebter Religion. Gütersloh: Chr. Kaiser/Gütersloher Verlagshaus.

Gräb W 2002. Sinn fürs Unendliche. Religion in der Mediengesellschaft. Gütersloh: Chr. Kaiser/Gütersloher Verlagshaus.

Gräb, W 2006. Religion als Deutung des Lebens. Perspektiven einer Praktischen Theologie gelebter Religion. Gütersloh: Gütersloher Verlagshaus.

Harder, G 1978. Soul. In: C Brown (ed.) Dictionary of New Testament Theology. Vol III. Exeter: Paternoster Press, 686-687.

Hawkins, D 2009. Map of consciousness. http://www.globalvoicesradio.org/map.html

Hopkins, DN 2005. Black Theology: the Notion of Culture Revisited. In: Journal of Theology for Southern Africa, 124, 74-83.

Karle, I 2009. Krankheitsdeutungen in gegenwärtigen Bewährungsfeldern - praktischtheologische Perspektiven. In: G Thomas, I Karle Krankheitsdeutung in der postsäkularen Gesellschaft. Theologische Ansätze im interdisziplinären Gespräch. Stuttgart: Kohlhammer, 543-556.

Landmesser, C 2005. Rudolf Bultmann: Religion, Kultur und Existence. In: V Drehsen et al. Kompendium Religionstheorie. Göttingen: Vandenhoeck and Ruprecht, 120-134.

Lartey, EY 1997. In Living Colour. An Intercultural Approach to Pastoral Care and Counselling. London: Cassell.

Link, H-G and A Ringwald 1978. Virtue (aretē). In: C Brown (ed.) Dictionary of New Testament Theology. Vol. II. Exeter, Paternoster Press, 925-931.

Louw, DJ 1999. A Mature Faith. Spiritual Direction and Anthropology in a Theology of Pastoral Care and Counselling. Louvain: Peters Press.

Louw, DJ 2008. Cura Vitae. Illness and the Healing of Life. Wellington: Lux Verbi. 
Marinoff, L 199. Plato not Prozac! Applying Eternal Wisdom to Everyday Problems. New York: Quill.

Meininger, HP 2001. Authenticity and Practice of an Inclusive Anthropology in Care for Persons with Intellectual Disabilities, In: W C Gaventa et al. Spirituality and Intellectual Disability: International Perspectives on the Effect of Culture and Religion on Healing Body, Mind and Soul. New York/London/Oxford: The Haworth Pastoral Press, 13-28.

Moore, T 1992. Care of the Soul. How to Add Depth and Meaning to your Everyday Life. London: Piatkus.

Nauer, D 2005. Pleidooi voor zielzorg. In: Praktische Theologie, 4, 465-483.

Niebuhr, HR 1952. Christ and Culture. London: Faber and Faber.

Nouwen, HJM 2000 4 . Show Me the Way. London: Darton, Longman and Todd.

Osmer, RR 2008. Practical Theology. An Introduction. Grand Rapids: Eerdmans.

Pohl, CD 1999. Making room. Recovering Christian Hospitality as a Christian tradition. Grand Rapids: Eerdmans.

Poling, JN 2002. Wahrnemung kultureller Differenz und die Machtfrage. DreiStufen kultureller Analyse. In: K Federschmidt et al, Interkulturelle Seelsorge. NeukirchenVluyn: Neukirchener Verlag, 63-80.

Praxis 2009. http://en.wikipedia.org/wiki/Praxis_(process).

Reddie, AG 2008. Dramatic Improvisation: A Jazz Inspired Approach to Undertaking Theology with the Marginalized. In: Llewellyn, D, DF Sawyer, Reading spiritualities. Constructing and representing the sacred. Aldershot: Ashgate, 51-65.

Ridley, CR, DW Lingle 1989³ . Cultural Empathy in Multicultural Counseling. A Multidimensional Process Model. In: JB Perderson et al, Counselling Across Cultures. Honolulu: University of Hawaii Press, 21-46.

Scneider-Harpprecht, 2002. Was ist interkulturelle Seelsorge? Eine praktisch-theologische Annäherung. In: K Federschmidt et al, Interkulturelle Seelsorge. Neukirchen-Vluyn: Neukirchener Verlag, 38-62.

Schipani, DS 2003. The Way of Wisdom in Pastoral Counseling. Elkhardt: Institute of Menonite Studies.

Seidl, H 1999. Seele. Kirchen und Philosophie geschichtlich. In: J Muller (hrsg.) Theologische Realenzyklopädie. Bd 30. Berlin: Walter de Gruyter, 748-759.

Starr, G $1981^{10}$. The Ancient Greeks. London: Oxford University Press.

Sutherland, A 2006. I was a stranger. A Christian Theology of Hospitality. Nashville: Abingdon.

Van Binsbergen, W 2003. Intercultural Encounters. African and Anthropological Lessons towards a Philosophy of Interculturality. Münster: Lit Verlag

Villa-Vicencio, C 1994. Theology and Culture in South Africa: Beyond Multi-Culturalism. In: Theology Today, 51/2, 115-126.

Vosloo, R 2004. Identity, otherness and the Triune God: Theological groundwork for a Christian ethics of hospitality. Journal of Theology for Southern Africa, 119, 69-89.

Vosloo, R 2006. Engele as gaste. Oor gasvryheid teenoor die ander. Wellington: Lux Verbi. 
Weiss, H 2002. Die Entdeckung Interkultureller Seelsorge. Entwicklung interkultureller Kompotenz in Seelsorge und Beratung durch internationale Begegnung. In:

K Federschmidt et al, Interkulturelle Seelsorge. Neukirchen-Vluyn: Neukirchener Verlag, 17-37.

Watson, P 2000. A Terrible Beauty. The People and Ideas the Shaped the Modern World. London: Phoenix Press. 